\title{
ВУЛКАНОГЕННЫЕ ПРОСЛОИ В БАЖЕНОВСКОЙ СВИТЕ ЗАПАДНО-СИБИРСКОГО ОСАДОЧНОГО БАССЕЙНА
}

\author{
Кондрашова Елена Сергеевна 1,2 , \\ deevael@yandex.ru \\ 1 Национальный исследовательский Томский политехнический университет, \\ Россия, 634050, г. Томск, пр. Ленина, 30. \\ 2 АО «ТомскНИПИнесть», \\ Россия, 634050, г. Томск, пр. Мира, 72
}

\begin{abstract}
Актуальность. Детальное изучение вещественного состава и особенностей строения выделенных в отложениях баженовской свиты вулканогенных горизонтов позволит уточнить закономерности их регионального формирования и распределения на территории Западно-Сибирского осадочного бассейна, а также получить новые данные о вулканизме, проявленном в верхнеюрское время на территории исследования.

Цель: определение особенностей состава и строения аномально люминесцирующих горизонтов баженовской свиты, доказывающих их вулканогенное происхождение, а также поиск закономерностей их распределения на территории исследования.

Объекты: осадочные породы, люминесцирующие прослои и вмещающие отложения баженовской свиты.

Методы: рентгенофазовый анализ, петрографический анализ.

Результаты. В иентральной и юго-восточной части Западно-Сибирского осадочного бассейна в отложениях баженовской свиты обнаружены люминесцирующие в ультраффиолетовом освещении прослои мощностью 0,2-45 см. Изучение минерального состава, особенностей строения и структурно-текстурных признаков выделенных горизонтов позволило определить природу их образования как вулканогенно-пирокластическую. Предполагается, что исследуемые прослои образовались в результате диа- и катагенетического преобразования вулканокластического материала туфовых осадков в обстановке застойного моря с высоким содержанием органического вещества. По результатам проведенных исследований выявлены два типа вулканогенных горизонтов, которые отличаются друг от друга по минеральному, петрографическому и химическому составу. Первый горизонт отнесен к глинистому типу. Он сложен в основном глинистыми минералами (каолинитом и смешаннослойными минералами иллит-смектитового ряда) с примесью обломочного алевритового материала. Второй горизонт характеризуется преимущественно кремнистым (квариевым) составом и отнесен к кремнистому типу. Каждый из выделенных горизонтов обособлен в разрезе и соответствует своему вулканическому событию позднеюрского времени.
\end{abstract}

\section{Ключевые слова:}

Западная Сибирь, баженовская свита, минералогия, петрограффия, вулканогенный материал.

\section{Введение}

В центральной и юго-восточной части ЗападноСибирского бассейна (площадь исследования охватывает около 500 км с запада на восток и около 400 км с севера на юг) в отложениях баженовской свиты автором были обнаружены «необычные» прослои, обладающие характерной особенностью - аномальным ярким люминесцирующим свечением в ультрафиолетовом свете. Изучаемые прослои были отмечены в 63 скважинах на 12 площадях (месторождениях) в центральной части Западно-Сибирского бассейна - Широтное Приобье (Ханты-Мансийский автономный округ, далее ХМАО) и в 41 скважине на 30 площадях (месторождениях) в юго-восточной части бассейна (Томская область). Ранее проведённые исследования петрографии и минералогии выделенных прослоев подтвердили их вулканическое происхождение [1-4].

Присутствие вулканогенного материала в юрских отложениях Западно-Сибирского бассейна, в том числе и в породах баженовской свиты, отмечалось многими исследователями [5-13].

В западной части Западно-Сибирского осадочного бассейна (Шаимский, Красноленинский, СевероСосьвинский и Салымский районы) описаны наиболее обогащенные вулканическим материалом верхнеюрские разрезы. По данным А.В. Вана и соавторов, вулканогенные прослои представлены в основном литокластическими туфами и туффитами, туфогенными аргиллитами, туфоалевролитами [7]. По данным Л.В. Ровниной и соавторов, на всей территории центральной части в породах баженовской свиты встречается вулканогенный материал в разном количестве и разной степени сохранности [6]. В работе Г.Н. Черкасова и др. указано, что пирокластический материал в верхнеюрских отложениях (оксфорд-киммериджтитон) в Приенисейской зоне Западно-Сибирской плиты представлен туфами риолитов и дацитов, туфогенными аргиллитами, известковыми литокластическими туффитами [12].

И.В. Панченко с соавторами, Е.Е. Оксенойд и Т.Д. Булатовым, а также В.А. Бумагиной и соавторами отмечены подобные тонкие глинистые прослои туфов и туффитов, обладающие яркой люминесценцией в центральной части Западно-Сибирского бассейна (Среднее Приобье) [9-11, 13].

Некоторые исследователи выражают сомнение в присутствии и значительном влиянии в породах баженовской свиты вулканогенного и эксгалятивного материала [14].

Актуальность проведенной работы обусловлена поступлением новых данных о присутствии вулканогенного материала в отложениях баженовской свиты 
в юго-восточной и центральной части ЗападноСибирского бассейна. Проведено детальное изучение строения выделенных вулканогенных прослоев и их типизация по структурно-текстурным особенностям и вещественному составу. Изучение особенностей состава и строения прослоев позволит получить новые данные о проявлении вулканизма в породах баженовской свиты и определить закономерности распространения вулканогенного материала на исследуемой территории.

\section{Характеристика объекта исследования}

При изучении отложений баженовской свиты обнаружены прослои с яркой люминесценцией в ультрафиолетовом освещении от желтого до оранжевого цвета.

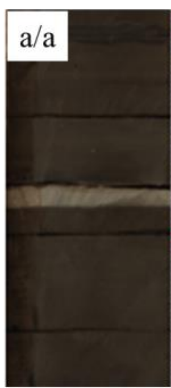

Дневной свет Day light

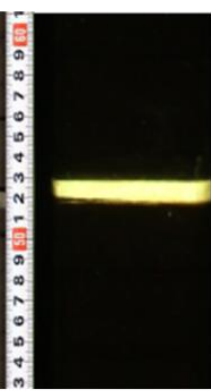

УФ свет

UF light

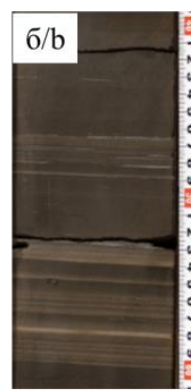

Дневной свет/ Day light

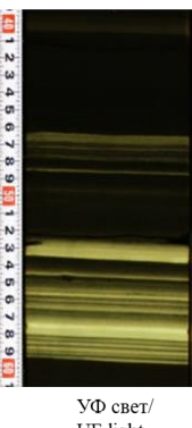

UF light
Рис. 1. Фотографии люминесцирующих прослоев в керне скважин: а) прослои I группь;; б) прослои II групnы. Фотографии керна выполнены в дневном и ультрафиолетовом (УФ) свете

Fig. 1. Photo of luminescent layers in the core of wells: a) layers of I group; b) layers of II group. Photo have done in daylight and ultraviolet (UV) light

Выявленные люминесцирующие прослои по комплексу признаков (цвет, мощность, текстура) разделены на две группы. I группа представляет собой прослои мощностью 0,2-1,5 см (рис. 1,a). II группа ритмичное переслаивание с суммарной мощностью 5-45 см, состоящее из тонких люминесцирующих слойков и слойков без свечения, обогащенных органическим веществом (рис. 1, б). В пределах разреза одной скважины нередко отмечается одновременное нахождение прослоев разных групп. При этом еди- ничные маломощные прослои I группы всегда находятся выше по разрезу, чем прослои II группы. Расстояние между группами составляет 1,5-10 м (рис. 2, a).

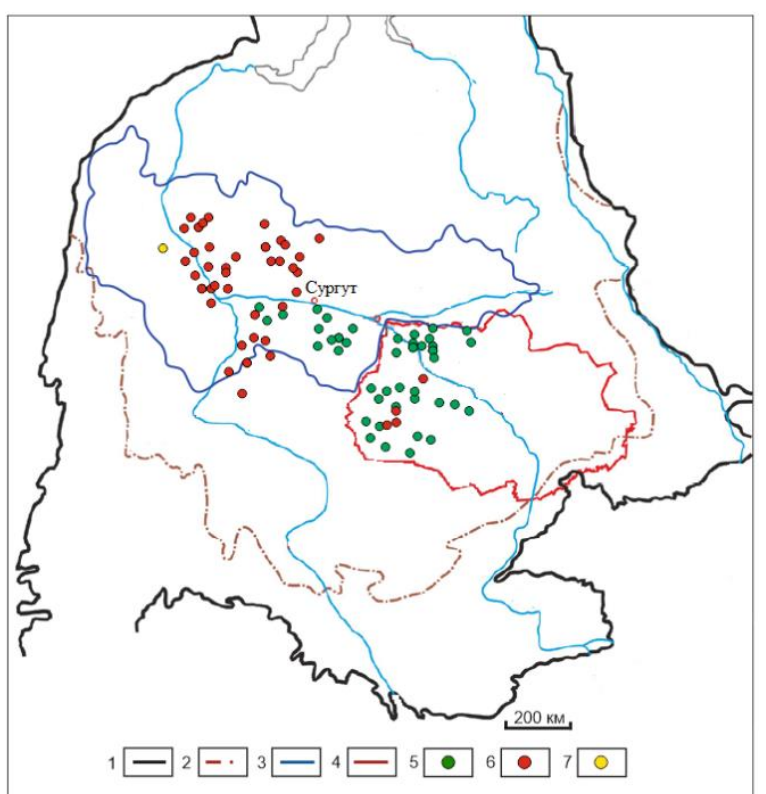

Puc. 2. Схема распределения площадей (месторождений) с выделенными вулканогенными люминесиирующчими горизонтами на территории ЗападноСибирской плитыл. 1 - границь ЗападноСибирской плиты;; 2 - граница распространения юрских отложений; 3 - территориальная граница ХМАО; 4 - территориальная граница Томской области; 5-7 - площади с выявленными люминесцирующими прослоями: 5 - по данным Е.C. Кондрашовой [4]; 6 - по данным И.В. Панченко и др. [9, 10]; 7 - по данным В.А. Бумагиной и др. [13]

Fig. 2. Scheme of distribution of areas (deposits) with distinguished volcanogenic luminescent horizons in the Western Siberian plate. 1 - boundaries of the Western Siberian plate; 2 - boundary of distribution of Jurassic deposits; 3 - territorial border of the Khanty-Mansi Autonomous Okrug; 4 - territorial border of the Tomsk region; 5-7 - areas with identified luminescent interlayers: 5 - according to E.S. Kondrashova [4]; 6 - according to I.V. Panchenko et al. [9, 10]; 7 - according to V.A. Bumagina et al. [13]

Таблица. Минеральный состав образцов люминесцирующих прослоев баженовской свиты, \% Table. $\quad$ Mineral composition of samples of luminescent layers of the Bazhenov formation, \%

\begin{tabular}{|c|c|c|c|c|c|c|c|c|c|}
\hline $\begin{array}{c}\text { Группа } \\
\text { прослоев } \\
\text { Layers group }\end{array}$ & $\begin{array}{l}\text { Тип прослоев } \\
\text { Туре of layers }\end{array}$ & $\begin{array}{c}\text { Каолинит } \\
\text { Kaolinite }\end{array}$ & $\begin{array}{c}\mathrm{CCM}^{*} \\
\text { Mixed layer } \\
\text { minerals }\end{array}$ & $\begin{array}{l}\text { Иллит } \\
\text { Illite }\end{array}$ & $\begin{array}{l}\text { Кварц } \\
\text { Quartz }\end{array}$ & $\begin{array}{c}\text { ПШ* } \\
\text { Feldspars }\end{array}$ & $\begin{array}{c}\text { Карбонатные минералы } \\
\text { Carbonate minerals }\end{array}$ & $\begin{array}{l}\text { Пирит } \\
\text { Pyrite }\end{array}$ & $\begin{array}{l}\text { Барит } \\
\text { Barite }\end{array}$ \\
\hline \multirow[t]{2}{*}{ The } & $\begin{array}{l}\text { Глинистый тип/Тип A } \\
\text { Clay type/Type A }\end{array}$ & $60-80$ & $10-30$ & $1-2$ & $1,5-6$ & $1-5$ & $1-2$ & $3-5$ & $1-5$ \\
\hline & $\begin{array}{l}\begin{array}{l}\text { Глинистый тип/Тип Б } \\
\text { Clay type/Тype B }\end{array} \\
\end{array}$ & $3-20$ & $60-80$ & $1-3$ & $1-5$ & $2-10$ & $0-1$ & $3-5$ & $1-5$ \\
\hline II & $\begin{array}{l}\text { Кремнистый тип } \\
\text { Siliceous type }\end{array}$ & $1-2$ & - & $1-2$ & $70-90$ & $1-7$ & $1-3$ & $1,5-6$ & - \\
\hline
\end{tabular}

Примечание: ССМ*_-смешаннослойные минералы, ПШ ${ }^{* *}$ - полевые шпаты. 
Выделенные люминесцирующие прослои были обнаружены автором более чем в 100 скважинах в юго-восточной и центральной частях ЗападноСибирского осадочного бассейна. Площадь территории исследования охватывает около 500 км с запада на восток и около 400 км с севера на юг (рис. 2).

По результатам ранее проведенных исследований установлен минеральный состав каждой выделенной группы прослоев [1, 4]. На основе полученных данных была произведена типизация прослоев по минеральному составу (таблица). Породы І группы прослоев отнесены к глинистому типу. По результатам рентгенофазового анализа (РФА) основными компонентами в них являются глинистые минералы (60-80 \%) - каолинит и смешаннослойные минералы (CСМ) иллит-смектитового ряда. По преобладающему минеральному компоненту породы разделены на два типа: тип А - преобладающий компонент - каолинит, тип Б - смешаннослойные минералы.

Главным минеральным компонентом состава образцов II группы является кварц (до 90 \%), на основании чего данная группа прослоев отнесена к кремнистому типу.

\section{Методика исследования}

Для проведения исследования были выбраны скважины, пробуренные в центральной и юговосточной части бассейна, в разрезах которых выделенные прослои обладают наиболее ярким и интенсивным свечением в УФ свете, а также с достаточной для проведения анализов мощностью. Образцы отобраны непосредственно из люминесцирующих прослоев и вмещающих их глинисто-кремнистых пород.

Для изучения минерального состава и особенностей строения люминесцирующих прослоев и вмещающих их пород применялся петрографический и рентгенофазовый анализ. Исследования проводились автором в лаборатории седиментологии АО «ТомскНИПИнефть». Петрографический анализ выполнялся с использованием поляризационного микроскопа Olympus BX51 со встроенной цифровой камерой. Количественный рентгенофазовый валовый анализ проводился с использованием рентгеновского дифрактометра RIGAKU Ultima IV.

\section{Результаты исследования и их обсуждение}

Природа образования люминесцирующих прослоев глинистого типа

Изученные прослои глинистого типа по особенностям вещественного состава, структурным и текстурным признакам, выявленным при изучении прослоев петрографическим и рентгенографическим методами, отнесены к породам со значительной примесью пирокластического пеплового материала.

Одним из ярких признаков вулканогенной (пепловой) природы формирования прослоев служат их текстурно-структурные особенности и особенности распределения в отложениях. Для изучаемых прослоев глинистого типа характерна более светлая окраска, ровные четкие границы с выше- и нижележащими от- ложениями (рис. 1, а). Мощность прослоев составляет $0,1-1,2 \mathrm{~cm}$.

По результатам петрографического исследования породы данной группы представлены аргиллитами с примесью разнозернистого алевритового (до псаммитового) обломочного материала. Текстура неясная, волнисто-слоистая, подчеркнутая тонкими намывами органического вещества (OB), аутигенным пиритом и чешуйками глинистых минералов. Соотношение глинистой матрицы и обломочного материала в породах составляет 70/30. Основная масса породы сложена неразличимым глинисто-гидрослюдистым материалом. Глинистые минералы по данным РФА представлены каолинитом, ССМ иллит-смектитового ряда, редко иллитом/мусковитом. Глинистые частицы имеют волокнистую, чешуйчатую и спутанную форму.

Среди обломочной части отмечаются остроугольные, копьевидные зерна кварца, реже таблитчатые зерна полевых шпатов (ПШ), мало подверженные постседиментационным преобразованиям. Для пород характерно неравномерное, чаще градационное (по направлению к нижней границе слоя) распределение несортированного обломочного материала (рис. 3, $a$, б). На контакте слоя наблюдаются угловатые обломочные зерна, вдавленные, врезанные во вмещающий нижний слой (рис. 3, в, 2). Отмечаются обломки пород, которые структурно и по оптическим признакам напоминают обломки кремнистых пород и/или окремненных кислых эффузивных пород (по составу соответствующих риолитам). Отмечаются также обломки кремнисто-глинистого состава.

Bce описанные выше признаки могут свидетельствовать о наличии в осадке материала вулканогенного (пеплового) происхождения и последующего его постседиментационного преобразования. Предполагается, что слагающие основную массу прослоев глинистые минералы имеют аутигенное происхождение и являются результатом вторичного преобразования пеплового материала (преимущественно вулканического стекла) на стадии диа- и катагенеза.

При анализе полученных результатов исследований минерального состава и сопоставлении их с местонахождением изучаемых разрезов отмечено, что прослои с преимущественно каолинитовым составом характерны для разрезов юго-восточной части бассейна, а прослои со смешаннослойным составом - для разрезов центральной части. Предполагается, что отложения свиты в юго-восточной части в своем составе имеют большее количество обломочного материала (ПШ, обломков пород) из-за близости источника сноса и претерпели более значительную проработку постседиментационными процессами.

По мнению А.В. Вана и Ю.П. Казанского полное преобразование почти каждой алюмосиликатной породы приводит к образованию каолинита, а частичное - к образованию монтмориллонита. Образование каолинита по алюмосиликатным минералам происходит под воздействием более интенсивных процессов выщелачивания и разложения (чем при образовании монтмориллонита) [5]. 

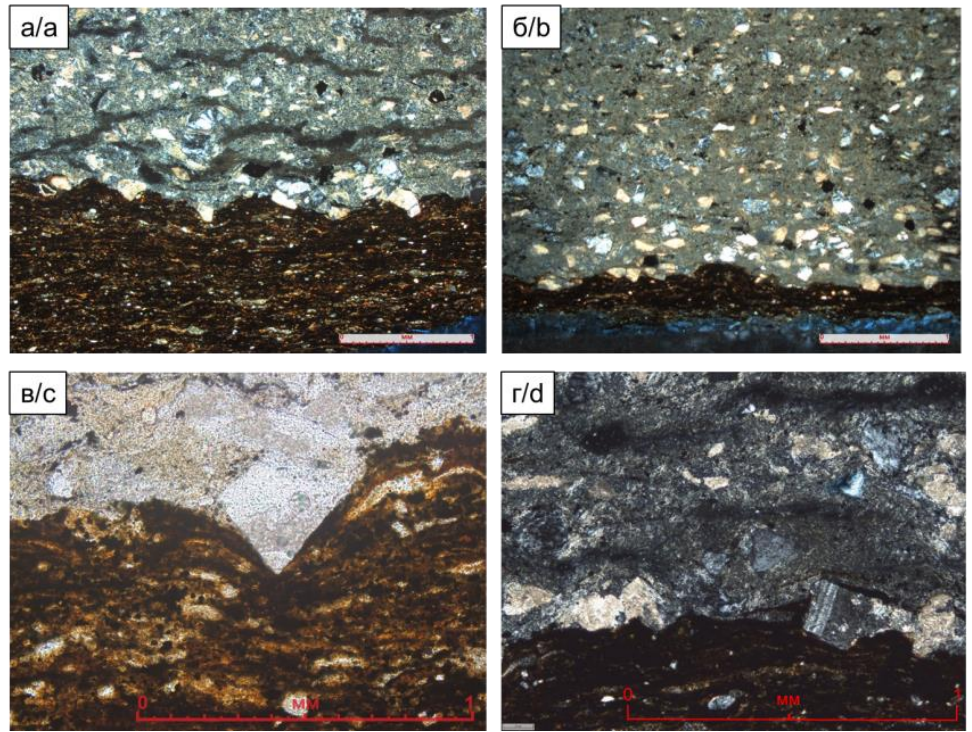

Pис. 3. Микрофотографии люминесиирующчих прослоев глинистого типа: а, б) граница прослоя и обогащенных ОВ вмещающих пород, неравномерное (градационное) распределение несортированного обломочного материала в основной глинистой массе породы; в, г) обломочные зерна на границе прослоя. а, б, г-с анализатором, вбез анализатора.

Fig. 3. Photomicrographs of luminescent layers of clay type: $a, b)$ boundary of layer and host rocks enriched with organic matter, uneven (gradational) distribution of unsorted clastic material in the clay matrix; $c, d)$ clastic grains at the boundary of the layer. $a, b, d$-cross-polarized light, $c$-plane-polarized light

На пепловую природу образования прослоев глинистого типа также указывают ранее выявленные геохимические особенности пород [2, 4]. Об этом свидетельствует, например, аномально высокое содержание тория в породах (диапазон концентраций 44,7-77,3 г/т). Наиболее вероятным источником поступления тория в исследуемые породы может служить вулканогенный пепел риолитового или щелочно-риолитового состава. Выделенные торийсодержащие горизонты имеют незначительные мощности (до 1 см), но при этом простираются на сотни километров и могут являться следствием обширного пеплопада в верхнеюрское время.

Для прослоев глинистого типа также характерно низкое содержание органического вещества. По ранее полученным данным пиролитического метода содержание $\mathrm{C}_{\text {орг }}$ составляет 0,2-2,7 \% [4]. Предполагается, что понижение концентраций ОВ в исследуемых горизонтах вызвано резкой сменой условий при осадконакоплении в иловых водах. Подобные условия могут быть вызваны единовременным поступлением в осадок пирокластического пеплового материала и его смешивание с осадками нормальной морской седиментации. Пепловые продукты обладают высокой реакционной способностью, также в них могут присутствовать токсичные элементы ( $\mathrm{Hg}, \mathrm{Cd}$, As и др.), что может оказывать пагубное влияние на жизнедеятельность организмов и приводить к их гибели $[15,16]$. Отмечено, что содержание As в исследованных породах глинистого типа составляет 33 г/т, что почти в два раза превышает его содержание во вмещающих породах [4].

Особенности распределения редкоземельных элементов, полученные значения лантан-иттербиевого отношения и титанового модуля, положение изучае- мых образцов на диаграмме Дж.А. Винчестера и Р.А. Флойда указывают на кислый риолит-дацитовый состав исходного пеплового материала при формировании глинистого типа прослоев [4].

Таким образом, природа формирования аномально люминесцирующих прослоев глинистого типа определена как вулканогенная пепловая, а породы могут быть названы туфогенными аргиллитами.

Подобные глинистые прослои с яркой люминесценцией в породах баженовской свиты на территории центральной части бассейна были выявлены и описаны в работах И.В. Панченко и соавторов, Е.Е. Оксенойд и Т.Д. Булатова, В.И. Афонина и соавторов [9-11, 17]. Согласно В.И. Афонину и соавторам в глинисто-кремнистых породах свиты установлены прослои туфов и прослои с обломками андезитов и их предположительная связь с крупными изверженными провинциями [17].

По данным И.В. Панченко и соавторов [9-11], Е.Е. Оксенойд и Т.Д. Булатова [11] в керне скважин баженовской свиты (Среднее Приобье) обнаружены серии темно-бурых тонких ярко люминесцирующих прослоев. По результатам исследований минерального состава показано, что прослои сложены преимущественно глинистыми минералами: смешаннослойными и каолинитом, также присутствуют ПШ, кварц, пирит и карбонатные минералы. По данным петрографического изучения шлифов авторами выявлено множество цеолитизированных зерен плагиоклаза, а также признаки присутствия пирокластического материала (идиоморфные, копьевидные зерна кварца и ПШ). По особенностям минерального и химического состава исследователи определили люминесцирующие прослои как туфы и туффиты. Ha TASдиаграмме образцы находятся в поле андезибазальтов 
нормальной щелочности. Результаты изучения минерального состава и особенности пород, выявленные в настоящей работе, сопоставляются с результатами вышеупомянутых авторов.

Дж.Д. Пирсом и соавторами выявлены тонкие прослои туфов в позднемеловых (турон-сеноман) нефтематеринских сланцах провинции Eagle Ford (США) [18, 19]. Данная провинция является аналогом битуминозных отложений баженовской свиты. Минеральный состав прослоев аналогичен с составом опи- санных в настоящей работе прослоев глинистого типа и имеет монтмориллонитовый, каолинитовый и смешаннослойный состав. В породах отмечаются угловатые вкрапленники кварца, плагиоклаза, санидина и глинистая матрица (рис. 4, $a, \sigma)$. Образцы из всех пепловых прослоев, изученных авторами, занимают поля базальтов-андезитов-дацитов, в единичных случаях риолитов (согласно TAS-диаграмме). Выделенные авторами прослои туфов также обладают люминесцирующим свечением в УФ свете (рис. 4,, , 2).
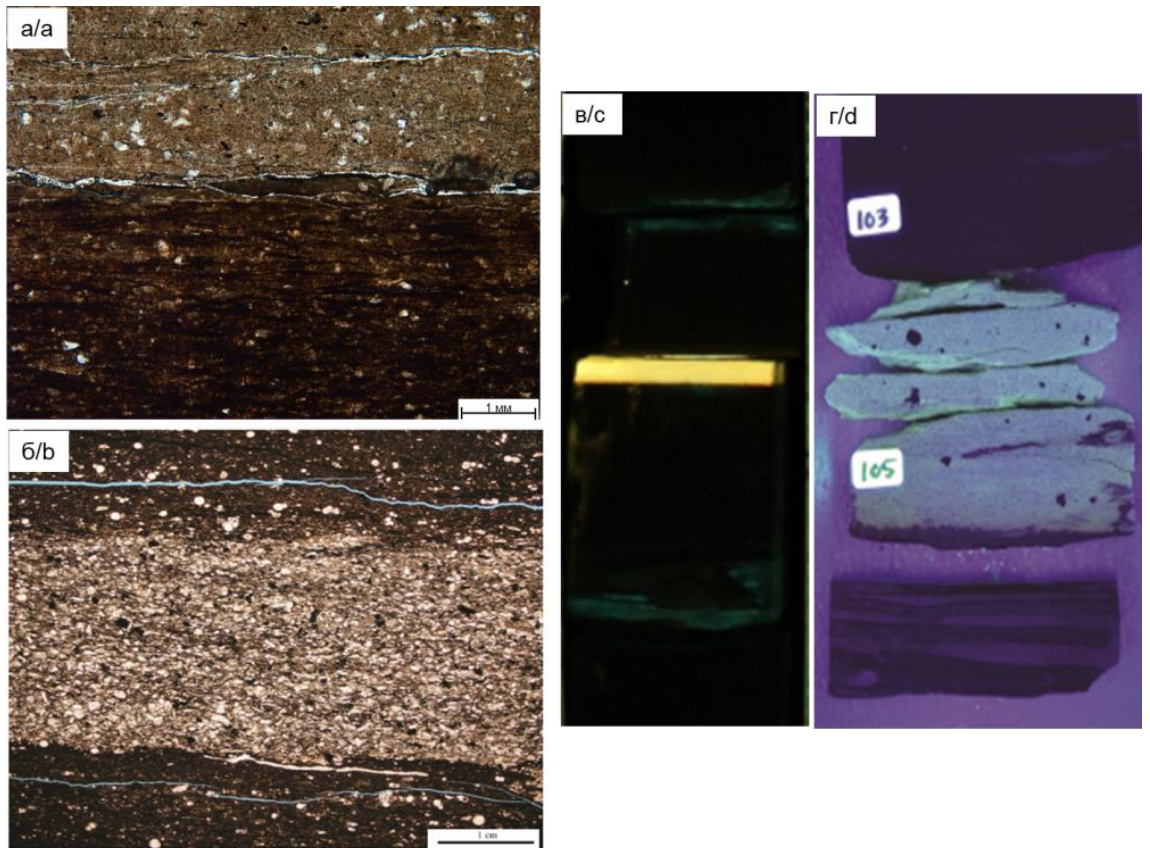

Рис. 4. Микрофотографии пепловых прослоев: а) люминесиирующие прослои глинистого типа в породах баженовской свиты; б) пепловые прослои в породах провинции Eagle Ford [18, 19]. Фотографии в УФ освещении: в) люминесцирующие прослои глинистого типа в породах баженовской свиты; г) пепловые прослои в породах провиниии Eagle Ford [18, 19]

Fig. 4. Photomicrographs of ash layers: a) luminescent clay-type layers in the rocks of the Bazhenov formation; $b$ ) ash layers in the rocks of the Eagle Ford province [18, 19]. Photos under UV light: c) luminescent clay-type layers in the rocks of the Bazhenov formation; d) ash layers in the rocks of the Eagle Ford province [18, 19]

Дискуссионным вопросом остается причина люминесценции выделенных горизонтов. По результатам ранее проведенных исследований причина свечения связывается с ОВ, а именно с особенностями его преобразования в условиях «ураганного» поступления пирокластического материала и резкой смены условий в иловых водах $[1,2,4]$. По мнению И.В. Панченко и соавторов, свечение пород первоначально связывалось с присутствием натролита [9], но в более поздней работе авторы связывают свечение с баритом [10]. В работах Дж.Д. Пирса и соавторов отмечается свечение прослоев в УФ свете, но, к сожалению, они не приводят никакую информацию об этом аспекте.

Природа образования люминесцирующих прослоев кремнистого типа

Для люминесцирующих прослоев кремнистого типа таких отчетливых признаков присутствия пирокластического пеплового материала, как для прослоев глинистого типа, не наблюдается, но характер самих прослоев и их положение в разрезе могут также сви- детельствовать об их формировании при вулканическом событии. Следует отметить, что подобные люминесцирующие прослои кремнистого состава в отложениях баженовской свиты ранее не были выявлены и изучены.

Пепловые туфы нередко образуют тонкое переслаивание, слагая ритмиты. Туфовые ритмиты возникают в результате периодического поступления и распределения пеплового материала при осаждении в водной среде [5]. Выделенные прослои кремнистого состава также напоминают ритмиты (рис. 5). Прослои имеют светлую окраску и также отчетливо определяются на фоне «обычных» пород баженовской свиты и характеризуются ритмичным чередованием светлых люминесцирующих слойков и слойков, обогащенных органическим веществом. Суммарная мощность таких кремнистых ритмитов составляет 5-45 см. Даже в пределах одной площади (месторождения) мощность таких прослоев в разных скважинах может отличаться. Предполагается, что мощность прослоев зависит от направления пеплового облака, морфологии дна 
бассейна, палеотечений и мощности осадков (темпа седиментации). В центре серий в большинстве случаев отмечается слоек с наиболее ярким свечением, вверх по разрезу свечение становится менее интен- сивным. Для люминесцируюших слойков характерны четкие ровные нижние границы и размытые верхние в виду смешивания с «обычным» не вулканогенным пирокластическим материалом.
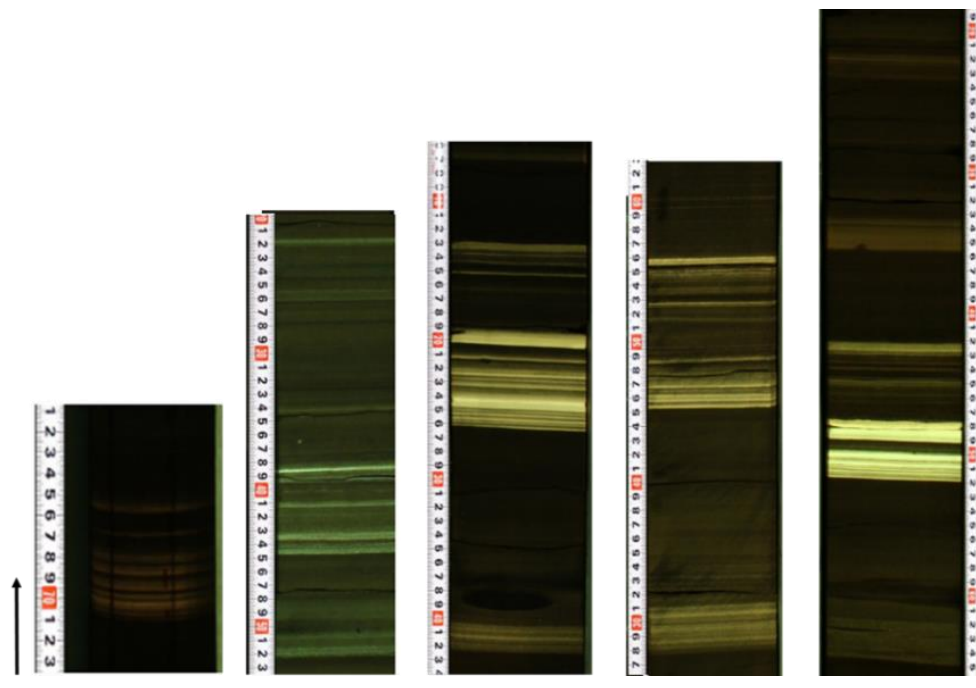

Рис. 5. Ритмичное переслаивание (серии) люминесцирующих слойков кремнистого типа. Фотографии керна в УФ cвете

Fig. 5. Rhythmic layering (series) of silicon type luminescent layer. Photo of core in UV light

При петрографическом изучении отмечено, что породы сложены кварцевым агрегатом (содержание кварца до 90 \%). Основную массу слагают лепидобластовые ориентированные зерна кварца с глинистогидрослюдистым цементом в подчиненном количестве. Предполагается, что породы претерпели значительное постседиментационное преобразование и по структурно-текстурным признакам соответствуют стадии метагенеза.
Породы по вещественному составу и текстурноструктурным признакам отнесены к алевролитам кварцевым и радиоляритам. В алевролитах отмечаются обломки линзовидной, уплощенной формы неясной природы. Обломки имеют микроструктуру, напоминающую раскристаллизованное вулканическое стекло (рис. 6). Контуры обломков не всегда четкие из-за неравномерного развития глинисто-гидрослюдистого цемента. Отмечаются остроугольные уплощенные зерна кварца (рис. 7).
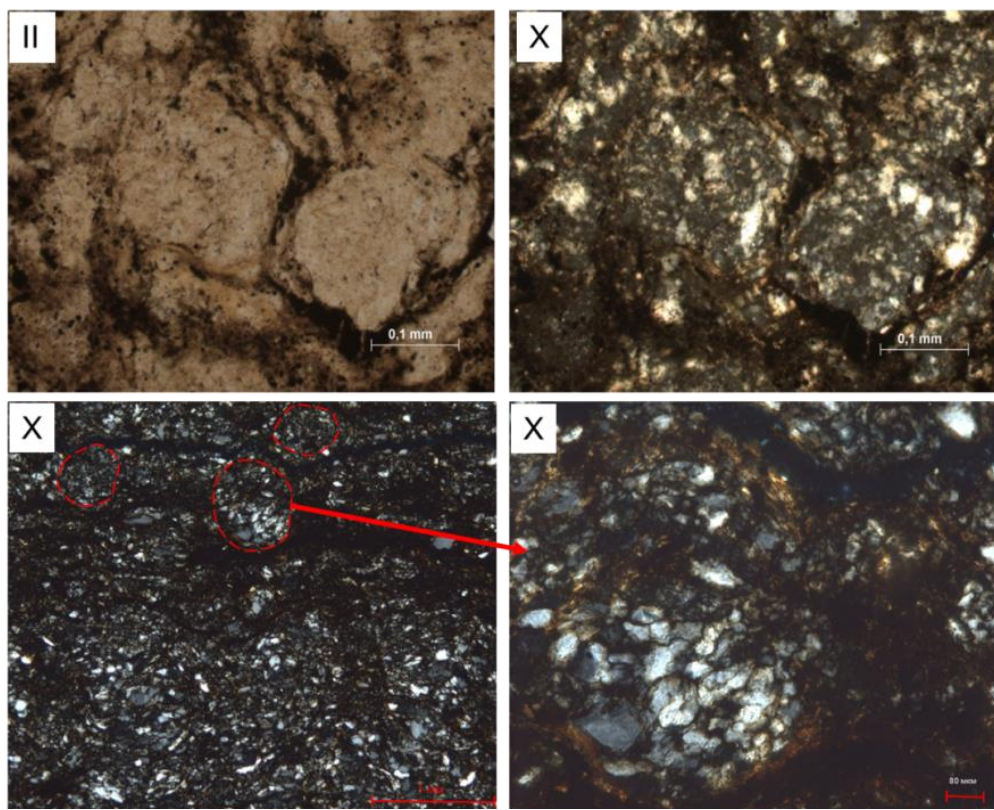

Pис. 6. Микрофотографии люминесцирующих прослоев кремнистого типа. Обломки пород (включения) линзовидной формы, предположстельно, раскристаллизованного вулканического стекла. II - без анализатора, $X-c$ анализатором

Fig. 6. Photomicrographs of luminescent siliceous layers. Fragments of rocks (debris) of lenticular form, presumably crystallized volcanic glass. II - plane-polarized light, X-cross-polarized light 

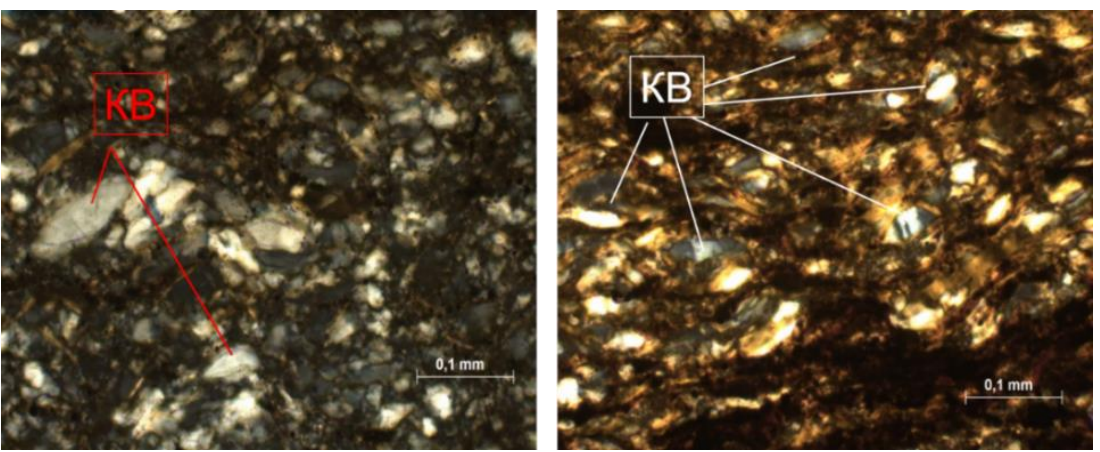

Рис. 7. Микрофотографии люминесцирующих прослоев кремнистого типа. Остроугольные обломки квариа в основной массе. КВ - квари. Фото с анализатором

Fig. 7. Photomicrographs of luminescent siliceous layers. Sharp-angled quartz fragments in the groundmass. KB - quartz. Cross-polarized light

Для кремнистых пород, представленных радиоляритами, явных признаков присутствия вулканогенного материала не наблюдается. Для радиоляритов характерны значительные процессы перекристаллизации и окремнения реликтов радиолярий.

При изучении отложений баженовской свиты многими специалистами в основании свиты выделяются кремнистые породы - силициты и глинистокремнистые породы [20-23]. По мнению исследователей, кремнезем имеет в основном биогенное происхождение, за счет обилия кремнийсодержащих организмов (радиолярии, реже диатомеи). В диагенетических и более поздних этапах постседиментационного преобразования отложений при уплотнении происходило растворение скелетов радиолярий, насыщение поровых вод кремнекислотой и последующее окремнение.

Широкое распространение кремнистых пород (силицитов) среди баженовских отложений нельзя объяснить одним лишь наличием кремнистых организмов. Многие исследователи объясняют обилие кремнистых отложений влиянием и проработкой осадка гидротермальными растворами на дне бассейна $[22,23]$. Насыщенный кремнекислотой материал подводных эксгаляций и растворов способствовал развитию организмов и формированию биогенных (радиоляриевых) толщ, а также формированию кремнистых (кварцевых) толщ. М.Ю. Зубков среди отложений свиты наряду с силицитами биогенного накопления (радиоляритами) выделяет гидротермальные силициты, представленные кремнистыми породами. Эти породы сложены многочисленными мелкими кристаллами гидротермального кварца. По данным автора, исходной породой, по которой образуются гидротермальные силициты, являются радиоляриты [23].

Е.А. Предтеченская, Л.Д. Молюшко, А.В. Ван и другие исследователи отмечают признаки подводной эксгалятивной деятельности в отложениях свиты (Рагозинская, Махнинская Ачимовская, Ноябрьская и других площади, Красноленинский и Салымский районы). Авторы описывают кремнистые и радиоляриевые силициты, для которых характерны повышенные значения геохимических модулей и высокие концентрации ряда элементов [7, 8, 22].
Некоторые исследователи подчеркивают роль влияния вулканизма на процессы окремнения пород. По данным Д.Д. Котельникова и А.И. Конюхова, наибольшее количество кремнезема освобождается при изменении кислого туфогенного материала [24]. Согласно М.Ю. Зубкову, источником кремнезема в породах свиты мог служить вулканический материал, который обогащал осадки кремнекислотой [23]. Поступление пирокластического материала в небольших количествах способствует привносу свободной кремнекислоты и благоприятному развитию жизнедеятельности организмов [5]. Напротив, мощное, ураганное кратковременное поступление столь реакционноспособного, зачастую обогащённого токсичными элементами, вулканического материала может и пагубно влиять на биопродуктивность, вплоть до массовой гибели организмов [15], что наблюдается в исследуемых кремнистых породах.

В работе А.В. Вана и Ю.П. Казанского среди туфов выделены окремненные туфы (туфогенные силициты), которые связаны постепенными переходами как с туфосилицитами, так и с собственно силицитами осадочного происхождения, что затрудняет их точное определение [5].

Природа образования аномально люминесцирующих прослоев кремнистого типа различна. Прослои представлены двумя литотипами - алевролитами кварцевыми и радиоляритами. Радиоляриты сформировались за счет биогенного накопления. Природа формирования алевролитовых кварцевых прослоев может быть объяснена тем, что породы после седиментогенеза, в начале диагенеза, подверглись гидротермальной проработке и дополнительному обогащению привнесенным кремнеземом, а также за счет растворения панцирей радиолярий и дополнительного окварцевания.

Влияние пирокластического материала на породы кремнистого типа опосредовано. Предполагается, что пепловый материал поступал «порционно» и в относительно небольших количествах в первоначально кремнистые породы (силициты, радиоляриты) и не подвергался процессам глинизации. Влияние пеплового материала распространялось только на жизнедеятельность присутствующих организмов. Реликты 
пеплового материала в породах наблюдаются только в виде редких угловатых, вытянутых зерен кварца.

Тот факт, что аномально люминесцирующие прослои кремнистого типа имеют слоистое строение и характеризуются чередованием люминесцирующих слойков без ОВ и слойков, обогащенных им, подтверждает влияние пирокластического материала на биопродуктивность, а также отражает ритмичность поступления вулканогенного материала в осадки.

\section{Схема формирования исследуемых прослоев}

Особенности строения, различия в микроэлементном и минеральном составе выделенных горизонтов говорит о разном масштабе проявления вулканической деятельности, в результате которой накопились исследуемые осадки.

На большей части площадей отмечено одновременное нахождение в разрезах скважин двух типов прослоев (кремнистых и глинистых) (рис. 8). Для некоторых площадей отмечено присутствие только глинистого типа прослоев, также присутствуют разрезы, в которых отмечены только прослои кремнистого типа, что может быть связано с особенностями накопления осадков в условиях неоднородного рельефа бассейна и с неравномерным характером оседания вулканогенного материала. Неполный отбор керна или же полное отсутствие баженовских отложений в каждой конкретной скважине затрудняет оценку наличия/отсутствия выделенных горизонтов.

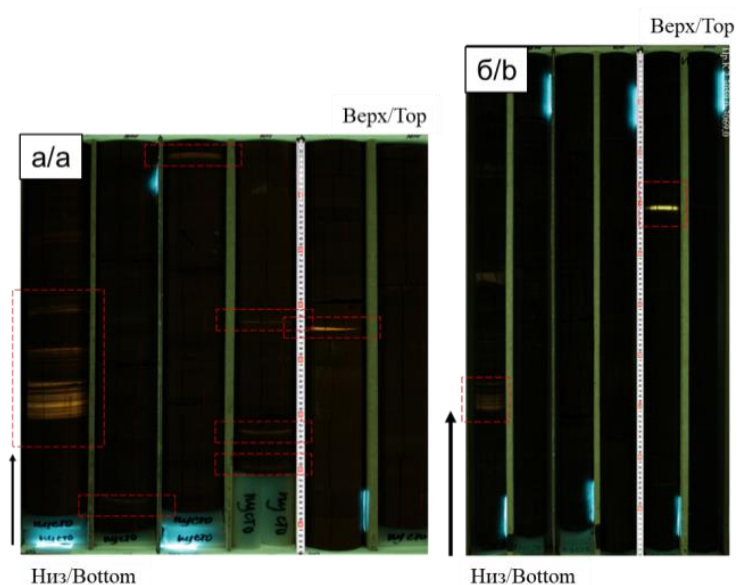

Рис. 8. Распределение люминесцируюших прослоев в разрезах скважин, вскрываюшчих баженовскую свиту: а) юго-восточная часть исследуемой территории (глубина 2384,3-2380,2 м); б) иентральная часть (глубина 3060,6-3066,4 м). Фотографии керна в УФ свете

Fig. 8. Distribution of luminescent layers in wells of the Bazhenov formation: a) the south-eastern part of the study area (depth 2384,3-2380,2 m); b) the central part (depth 3060,6-3066,4 m). Photo of core in UV light

Кремнистые прослои тяготеют к нижней, приподошвенной, части разрезов, выше них по разрезу распределены тонкие единичные глинистые прослои (ближе к средней части). Расстояние между горизонтами изменяется в переделах от 1 до 10 м, что, предположительно, связано с особенностями морфологии дна баженовского моря на период накопления пеплового материала, палеоветрами, палеотечениями и темпами седиментации. При этом для скважин, расположенных в юго-восточной части территории, отмечается меньшее расстояние между типами прослоев и составляет 1-5 м. Для данной части бассейна характерны меньшие мощности баженовской свиты, т. к. юго-восточная часть является периферийными областями распространения свиты. Для центральных районов Западной Сибири баженовская свита имеет большую мощность. На этой территории расстояние между типами прослоев увеличивается до 3-10 м.

Кремнистые прослои нижней части разреза чаще отмечаются в скважинах юго-восточной части территории, здесь суммарная мощность горизонтов 5-45 см. Тогда как прослои в центральных частях бассейна отмечаются реже и для них характерны меньшие мощности - 5-15 см. Расстояние от подошвы свиты до кремнистых горизонтов в юго-восточной части составляет 1,5-9 м, в центральной части бассейна $-15-22$ м.

Вверх по разрезу встречаются одиночные маломощные глинистые прослои. Количество таких прослоев по разрезу достигает 2-7 шт., мощность составляет 0,1-1,2 см. Расстояние между прослоями колеблется в разных пределах - от 1 до 6 м. В юговосточной части в разрезах обычно встречается 4-7 прослоев, расстояние между прослоями 1-2 м. Самый последний (верхний) прослой на данной территории самый мощный (до 1,2 см) и самый яркий по свечению. В центральной части бассейна количество прослоев меньше и составляет 1-4 шт. Расстояние между одиночными прослоями увеличивается и составляет 1-6 м. При этом над самым мощным и ярким прослоем появляется более тонкий слоек (до 0,3 см), чего не наблюдается в юго-восточной части. Для центральной и юго-восточной части расстояние от последнего (верхнего) прослоя до кровли свиты установить не удалось ввиду неполного объема керна в большинстве скважин.

Схема распределения прослоев в разрезе для двух исследуемых районов приведена на рис. 9.

Тот факт, что прослои кремнистого типа отмечены в нижней части разреза баженовской свиты и по геохимическим особенностям характеризуются более основным составом, а горизонты глинистого типа близки по составу к риолитам/дацитам и отделены от кремнистых прослоев временными интервалами, свидетельствует о том, что вулканогенный материал во время верхнеюрского накопления отложений свиты поступал неоднократно и пульсационно, таким образом, что между «выбросами» пеплового материала накапливались обогащенные ОВ осадки свиты. Такая схема вулканизма хорошо укладывается в современные представления о последовательности и частоте катастрофических извержений. Анализ строения вулканогенно-осадочных циклов или ритмов в осадочных толщах показывает, что распределение вулканокластического материала в них подчиняется определенной закономерности, выражающейся в изменении состава вулканических пеплов вверх по разрезу от основного к кислому [5]. 

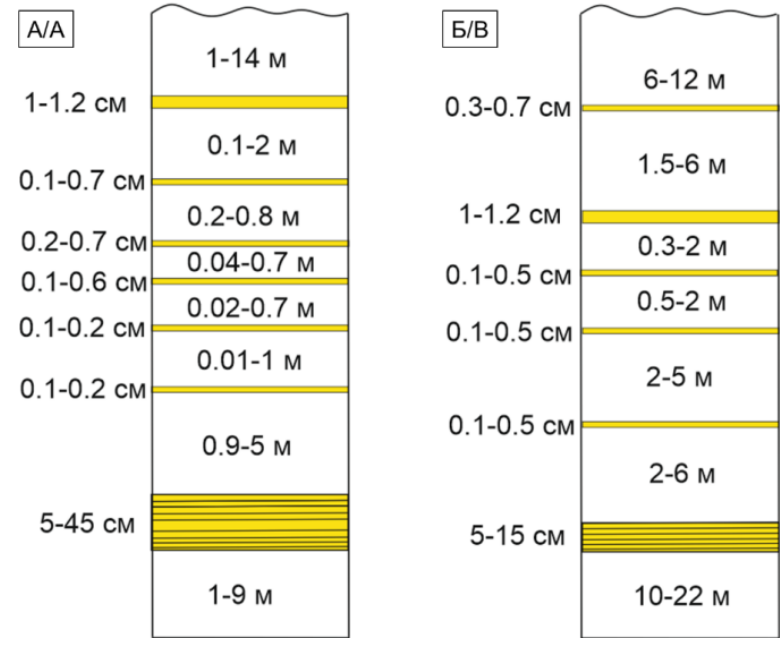

Рис. 9. Общая схема накопления и распределения люминесцирующих прослоев в разрезах скважин: $A$ для юго-восточной части территории; Б) для центральной части. В чентре указан диапазон расстояния между прослоями в метрах, справа сбоку - диапазон мощуности прослоев в сантиметрах

Fig. 9. General scheme of accumulation and distribution of luminescent layers in the well sections: A) for the southeastern part of the territory; $B$ ) for the central part. Values on the columns - distance between luminescent layers (meters); values on the right sitethickness of layers (centimeters)

Выделенные типы прослоев (как глинистые, так и кремнистые) распространены на всей территории исследования. Это свидетельствует о масштабности проявления вулканизма, который покрывал огромные площади. Продукты вулканической деятельности в отложениях баженовской свиты распределены неравномерно даже в пределах одной площади. Наличие участков (скважин) без присутствия вулканогенных горизонтов подчеркивает неравномерный характер оседания пеплов, неоднородный характер рельефа дна бассейна осадконакопления, роль палеотечений и смешивание пепловых осадков с осадочным материалом.

\section{Источник вулканогенного материала}

Вулканогенный, особенно пирокластический, материал является неустойчивым и, поступая в осадок, подвергается различным постседиментационным преобразованиям, что затрудняет его точное определение и дальнейший поиск источника вулканизма.

Западно-Сибирская плита почти со всех сторон обрамлена крупными сложно построенными структурами - тектоническими поясами, преимущественно герцинского возраста. Не на всех этих структурах в верхнеюрское время был проявлен магматизм и вулканическая деятельность, но некоторые области мог-

\section{СПИСОК ЛИТЕРАТУРЫ}

1. Петрография и минералогия глин аномально люминесцирующих прослоев баженовской свиты Западно-Сибирского осадочного бассейна / М.В. Шалдыбин, В.В. Крупская, А.В. Глотов, О.В. Доржиева, И.В. Гончаров, В.В. Самойленко, ли быть потенциальными источниками вулканогенного материала для изучаемых объектов на исследуемой территории.

Анализ распространения изучаемых прослоев на территории исследования выявил следующие закономерности. Частота встречаемости и мощность кремнистых прослоев выше в юго-восточной части территории. В центральной части Западно-Сибирского бассейна прослои кремнистого типа встречаются реже. Встречаемость прослоев глинистого типа уменьшается, а расстояние между прослоями увеличивается с юго-востока на запад, т. е. на юго-восточной территории глинистые пепловые прослои встречаются чаще и расстояние между прослоями меньше, чем в центральной части бассейна. Предполагается, что вероятным источником поступления вулканического материала могут являться области Саяно-Енисейской, Байкальской или Верхояно-Чукотской складчатости. Однако эти выводы требуют дополнительных исследований.

\section{Заключение}

Проведенные исследования вещественного состава, особенностей строения и текстурно-структурных признаков, а также минералого-геохимических особенностей люминесцирующих прослоев позволили определить природу их образования как вулканогенную-пепловую.

Изучаемые прослои по своим особенностям схожи с тонштейнами в угленосных отложениях (практически мономинеральными каолинитовыми горизонтами) и бентонитами (основной глинистый минерал - смектит). Формирование тонштейнов происходит за счет постседиментационного преобразования вулканического материла кислого состава [25-29]. Бентониты образуются путем подводного выветривания (гальмиролиза) падающего в бассейн седиментации (и оседающего на его дне) вулканического пепла с образованием смектитовых минералов [26, 29].

В результате проведенных исследований выявлены два типа вулканогенных горизонтов, которые отличаются друг от друга по минеральному, петрографическому и химическому составу, каждый из которых обособлен в разрезе и соответствует своему вулканическому событию позднеюрского времени.

Детальное изучение выделенных вулканогенных горизонтов позволяет оценить возможность их использования в качестве реперных горизонтов для уточнения палеогеографических реконструкций свиты и решения задач литостратиграфической корреляции ввиду их площадного регионального распространения.

Исследование выполнено при финансовой поддержке РФФИ в рамках научного проекта № 19-35-90008.

Е.С. Деева, Ю.М. Лопушняк, О.В. Бетхер, С.В. Закусин // Нефтяное хозяйство. - 2018. - № 2. - С. 36-40.

2. The nature, origin and significance of luminescent layers in the Bazhenov Shale Formation of West Siberia, Russia / M.V. Shaldybin, M.J. Wilson, L. Wilson, Yu.M. Lopushnyak, R. Brydson, V.V. Krupskaya, E.S. Kondrashova (Deeva), 
A.V. Glotov, I.V. Goncharov, V.V. Samoilenko, S.I. Arbuzov, O.V. Bether, L. Browen, D. White, N.V. Dorofeeva // Marine and Petroleum Geology. - 2019. - V.100. - P. 358-375.

3. Shaldybin M.V., Kondrashova E.S. The Jurassic global volcanic events recorded in sedimentary black shale deposits (Bazhenov formation, West Siberia) // Large Igneous Provinces through earth history: mantle plumes, supercontinents, climate change, metallogeny and oil-gas, planetary analogues: 7th International Science Conference. - Tomsk: Tomsk State University, 2019. P. $122-124$.

4. Кондрашова Е.С. Минералогия, геохимия и природа свечения люминесцирующих прослоев баженовской свиты ЗападноСибирского осадочного бассейна // Известия Томского политехнического университета. Инжиниринг георесурсов. 2020. - T. 331. - № 8. - C. 123-135.

5. Ван А.В., Казанский Ю.П. Вулканокластический материал в осадках и осадочных породах. - Новосибирск: Наука, Сибирское отделение, 1985. - $128 \mathrm{c}$.

6. Ровнина Л.В., Конышева Р.А., Садовникова Т.К. К вопросу о вещественном составе баженовской свиты Западной Сибири // Нефтеносность баженовской свиты Западной Сибири. - М.: ИГиРГИ, 1980. - С. 148-175.

7. Ван А.В., Предтеченская Е.А., Злобина О.Н. Продукты вулканизма в юрских отложениях Приуральской части ЗападноСибирской плиты // Геология, геофизика и разработка нефтяных и газовых месторождений. - 2011. - № 5. - С. 15-22.

8. Предтеченская Е.А., Малюшко Л.Д. Геохимические особенности и факторные модели баженовской свиты в центральных и юго-восточных районах Западно-Сибирской плиты // Известия Высших учебных заведений. Геология и разведка. 2016. - № 4. - C. 23-36.

9. Туфы и туффиты в баженовском горизонте (Западная Сибирь) И.В. Панченко, В.А. Камзолкин, А.В. Латышев, И.Д. Соболев // Эволюция осадочных процессов в истории Земли: VIII Bceроссийское литологическое совещание. - М.: РГУ нефти и газа имени И.М. Губкина, 2015. - Т. І. - С. 258-260.

10. Вулканические туфы и туффиты в пограничных отложениях юры и мела (волжский-рязанский ярусы) Западной Сибири / И.В. Панченко, И.Д. Соболев, М.А. Рогов, А.В. Латышев // Литология и полезные ископаемые. - 2021. - № 2. - С. 1-40.

11. Оксенойд Е.Е., Булатов Т.Д. Туфогенные прослои в отложениях баженовского горизонта в Среднем Приобье (Западная Сибирь) // Осадочная геология Урала и прилежащих регионов: сегодня и завтра: 12 Уральское совещание. - Екатеринбург: ИГГ УрО РАН, 2018. - С. 247-250.

12. Черкасов Г.Н., Беляев Н.В. Мезозойско-кайнозойская тектономагматическая активизация и позднемеловой - палеогеновый рудолитогенез в Приенисейской зоне Западно-Сибирской плиты. Ч. 1 // Геология и минерально-сырьевые ресурсы Сибири. - 2015. - № 3 (23). - С. 107-114.

13. Строение и условия формирования бажен-абалакского комплекса в пределах Красноленинского свода / В.А. Бумагина, А.С. Потапова, А.И. Кудаманов, В.А. Маринов, А.Т. Ахмадишин, А.С. Алифиров // Нефтяная провинция. - 2018. № 4 (16). - C. 86-108.

14. Ушатинский И.Н., Харин В.С. Типы и состав пород баженовской свиты // Строение и нефтеносность баженовской свиты Западной Сибири. - Тюмень: Изд-во ЗапСибНИГНИ, 1985. C. $54-64$
15. Неручев С.Г. Уран и жизнь в истории Земли. - Л.: Недра, 1982. $-208 \mathrm{c}$

16. Impact of Chaitén volcano ash fall on native and exotic fish recovery, recolonization, and abundance / C.Y. Prinzio, B. Penaluna, M.G. Grech, L.M. Manzo, L.M. Miserendino, R. Casaux // Science of the Total Environment. - 2021. - V. 752. Article 141864.

17. Preliminary data on the connection of the CA. 150 MA LIPs with the Bazhenov formatiom (Western Siberia) / I.V. Afonin, P.A. Tishin, A.V. Hitarova, R.E. Ernst, A.V. Kudamanov // Large Igneous Provinces through earth history: mantle plumes, supercontinents, climate change, metallogeny and oil-gas, planetary analogues: 7th International Science Conference. Tomsk: Tomsk State University, 2019. - P. 6-7.

18. Pierce J.D. U-Pb geochronology of the Late Cretaceous Eagle Ford Shale, Texas; defining chronostratigraphic boundaries and volcanic ash source: Thesis of Master of Science in Geological Sciences. - Austin, 2014. - $144 \mathrm{p}$

19. Zircon $\mathrm{U}-\mathrm{Pb}$ geochronology and sources of volcanic ash beds in the Upper Cretaceous Eagle Ford Shale, South Texas / J.D. Pierce, S.C. Ruppel, H. Rowe, D. Stockli // GCAGS Journal. - 2016. V. 5. - P. 253-274.

20. Классификация пород баженовской свиты / А.Э. Конторович, П.А. Ян, А.Г. Замирайлова, Е.А. Костырева, В.Г. Эдер // Геология и геофизика. - 2016. - Т. 57 (11). - С. 2034-2043.

21. Особенности литологического состава основных типов разрезов баженовской свиты / В.Г. Эдер, А.Г. Замирайлова, Ю.Н. Занин, И.А. Жигульский // Геология нефти и газа. 2015. - № 6. - С. 96-106.

22. Предтеченская Е.А., Злобина О.Н., Бурлева О.В. Минералогические и геохимические аномалии как индикаторы флюидодинамических процессов в юрских нефтегазоносных отложениях Западно-Сибирской плиты // Геология, геофизика и разработка нефтяных и газовых месторождений. - 2015. - № 1. C. $11-24$

23. Зубков М.Ю. Региональный и локальный прогнозы нефтеносности баженовской и абалакской свит (Западная Сибирь) // Горные ведомости. - 2016. - № 3-4. - С. 46-68.

24. Котельников Д.Д., Конюхов А.И. Глинистые минералы осадочных пород. - М.: Недра, 1986. - 247 с.

25. Nature of Tonsteins in the Azeisk Deposit of the Irkutsk Coal Basin (Siberia, Russia) / S.I. Arbuzov, A.M. Mezhibor, D.A. Spears, S.S. Ilenok, M.V. Shaldybin, E.V. Belaya // International Journal of Coal Geology. - 2016. - V. 152. - P. 99-111.

26. Spears D.A. The origin of tonsteins, an overview, and links with seatearths, fireclays and fragmental clay rocks // International Journal of Coal Geology. - 2012. - V. 94. - P. 22-31.

27. Euramerican tonsteins: overview, magmatic origin, and depositional-tectonic implications / P.C. Lyons, D.A. Spears, W.F. Outerbridge, R.D. Congdon, H.T. Evans // Palaeogeography, Palaeoclimatology, Palaeoecology. - 1994. - V. 106. - P. 113-134.

28. Altered volcanic ashes in coal and coal-bearing sequences: a review of their nature and significance / S. Dai, C.R. Ward, I.T. Graham, D. French, J.C. Hower, L. Zhao, X. Wang // EarthScience Reviews. - 2017. - V. 175. - P. 44-74.

29. Bohor B.F., Triplehorn D.M. Tonsteins: altered volcanic ash layers in coal-bearing sequences. - Colorado: The Geological Society of America, 1993. $-42 \mathrm{p}$.

Поступила 24.12.2020 2.

\section{Информация об авторах}

Кондрашова E.C., инженер отделения геологии Инженерной школы природных ресурсов национального исследовательского Томского политехнического университета; инженер сектора литологии АО «ТомскНИПИнефть». 
UDC 552.5:551.21:551.762

\title{
VOLCANOGENIC LAYERS IN BAZHENOV FORMATION OF THE WESTERN SIBERIAN SEDIMENTARY BASIN
}

\author{
Elena S. Kondrashova ${ }^{1,2}$, \\ deevael@yandex.ru \\ 1 National Research Tomsk Polytechnic University, \\ 30, Lenin avenue, Tomsk, 634050, Russia. \\ 2 Institute of oil and gas JSC «TomskNIPIneft», \\ 72, Mira avenue, Tomsk, 634050, Russia.
}

The relevance. The detailed study of the material composition and structural features volcanic horizons identified in the Bazhenov formation sediments will clarify their regional formation patterns and distribution in the territory of the Western Siberian sedimentary basin, as well as new data on volcanism, manifestations in the Upper Jurassic in the territory of the study.

The main objective is to determine the features of composition and structure of the abnormally luminescent horizons of the Bazhenov formation, proving their volcanogenic origin, as well as to search for distribution patterns in the study area.

Objects: sedimentary rocks, luminescent layers and enclosing rocks of the Bazhenov formation.

Methods: X-ray diffractometry, petrographic analysis.

Results. In the sediments of the Bazhenov formation in the central and south-eastern part of the Western Siberian basin, the layers with a thickness of 0,2-45 cm with luminescent in ultraviolet light were found. Study of the mineral composition, structural features, structural and textural features of the identified horizons allowed defining the origin of their formation as volcanogenic-pyroclastic. It is assumed that the identified layers were formed as a result of dia- and catagenetic transformation of the volcanoclastic material of tuff sediments in a stagnant sea with a high content of organic matter. In the course of the research two types of volcanogenic horizons were identified. They differ from each other in mineral, petrographic and chemical composition. The 1 st horizon is related to the clay type. It is composed mainly of clay minerals (kaolinite and mixed-layer minerals of the illite-smectite series) with admixture of detrital silty material. The $2^{\text {nd }}$ horizon refers to siliceous type, because it is characterized mainly by siliceous (quartz) composition. Each of the identified horizons is isolated in the section and corresponds to its own volcanic event of the Upper Jurassic time.

\section{Key words:}

Western Siberia, the Bazhenov formation, mineralogy, petrography, volcanogenic material.

The reported study was funded by RFBR, project number 19-35-90008.

\section{REFERENCES}

1. Shaldybin M.V., Krupskaya V.V., Glotov A.V., Dorzhieva O.V., Goncharov I.V., Samoylenko V.V., Deeva E.S., Lopushnyak Yu.M., Bether O.V., Zakusin S.V. Petrography and clay mineralogy of anomaly luminescent layers in Bazhenov suite of Western Siberia sedimentary basin. Oil-industry, 2018, no. 2, pp. 36-40. In Rus.

2. Shaldybin M.V., Wilson M.J., Wilson L., Lopushnyak Yu.M., Brydson R., Krupskaya V.V., Kondrashova (Deeva) E.S., Glotov A.V., Goncharov I.V., Samoilenko V.V., Arbuzov S.I., Bether O.V., Browen L., White D., Dorofeeva N.V. The nature, origin and significance of luminescent layers in the Bazhenov Shale Formation of West Siberia, Russia. Marine and Petroleum Geology, 2019, vol. 100, pp. 358-375.

3. Shaldybin M.V., Kondrashova E.S. The Jurassic global volcanic events recorded in sedimentary black shale deposits (Bazhenov formation, West Siberia). 7th International Science Conference. Large Igneous Provinces through earth history: mantle plumes, supercontinents, climate change, metallogeny and oil-gas, planetary analogues. Tomsk, CSTI Publ. house, 2019. pp. 122-124.

4. Kondrashova E.S. Mineralogy, geochemistry and the nature of the luminescent interlayers of the Bazhenov Formation of the West Siberian sedimentary basin. Bulletin of the Tomsk Polytechnic University. Geo Assets Engineering, 2020, vol. 331, no. 8, pp. 123-135. In Rus.

5. Van A.V., Kazanskiy Yu.P. Vulkanoklasticheskiy material v osadkakh i osadochnykh porodakh [Volcanoclastic material in sediments and sedimentary rocks]. Novosibirsk, Nauka Publ., Siberian departement, 1985. $128 \mathrm{p}$

6. Rovnina L.V., Konysheva R.A., Sadovnikova T.K. K voprosu o veshchestvennom sostave bazhenovskoy svity Zapadnoy Sibiri [On the issue of the material composition of the Bazhenov formation in Western Siberia]. Neftenosnost bazhenovskoy svity Za- padnoy Sibiri [Oil-bearing capacity of the Bazhenov formation in Western Siberia]. Moscow, Institute of Geology and Development of Fuels Publ., 1980. pp. 148-175.

7. Van A.V., Predtechenskaya E.A., Zlobina O.N. Produkty vulkanizma v yurskikh otlozheniyakh Priuralskoy chasti ZapadnoSibirskoy plity [Products of volcanism in Jurassic deposits of the Ural part of the West Siberian plate]. Geologiva, geofizika $i$ razrabotka neftyanykh $i$ gazovykh mestorozhdeniy, 2011, no. 5, pp. $15-22$.

8. Predtechenskaya E.A., Malyushko L.D. Geochemical features and factor models of the bazhenov formation in the central and southeastern regions of the West Siberian plate. Proceedings of higher educational establishments. Geology and Exploration, 2016, no. 4, pp. 23-36. In Rus.

9. Panchenko I.V., Kamzolkin V.A., Latyshev A.V., Sobolev I.D. Tufy i tuffity v bazhenovskom gorizonte (Zapadnaya Sibir) [Tuffs and tuffites in the Bazhenov horizon (Western Siberia)]. VIII Vserossiyskoe litologicheskoe soveshchanie. Evolyutsiya osadochnykh protsessov $v$ istorii Zemli [VIII All-Russian lithological meeting. Evolution of sedimentary processes in the history of the Earth]. Moscow, Russian State University of Oil and Gas named after I.M. Gubkin Publ., 2015. Vol. 1, pp. 258-260.

10. Panchenko I.V., Sobolev I.D., Rogov M.A., Latyshev A.V. Volcanic tuffs and tuffites at the Jurassic-Cretaceous boundary beds (Volgian-Ryazanian stages) of Western Siberia. Litologiya $i$ poleznye iskopaemye, 2021, no. 2, pp. 1-40. In Rus.

11. Oksenoyd E.E., Bulatov T.D. Tufogennye prosloi v otlozheniyakh bazhenovskogo gorizonta v Srednem Priobe (Zapadnaya Sibir) [Tufogenic interlayers in sediments of the Bazhenov horizon in the Middle Ob region (Western Siberia)]. XII Uralskoe soveshchanie. Osadochnaya geologiya Urala i prilezhashchikh regionov: segodnya i zavtra [XII Ural Meeting. Sedimentary Geology Urals and 
adjacent regions: today and tomorrow]. Ekaterinburg, IGG UrO RAN Publ., 2018. pp. 247-250.

12. Cherkasov G.N., Belyaev N.V. Mesozoic-cenozoic tectonicmagmatic activation and late cretaceous-paleogenic orelithogenesis in the Cis-Yenisei Zone of the West Siberian plate. Pt. 1. Geology and mineral resources of Siberia, 2015, no. 3 (23), pp. 107-114. In Rus.

13. Bumagina V.A., Potapova A.S., Kudamanov A.I., Marinov V.A., Ahmadishin A.T., Alifirov A.S. Structure and sedimentation environment of the bazhenovskian-abalakskian series within the Krasnoleninsky dome. Oil province, 2018, no. 4 (16), pp. 86-108. In Rus.

14. Ushatinskiy I.N., Kharin V.S. Tipy i sostav porod bazhenovskoy svity [Types and composition of rocks of the Bazhenov formation] Stroenie i neftenosnost bazhenovskoy svity Zapadnoy Sibiri [Structure and oil content of the Bazhenov formation in Western Siberia]. Tyumen, ZapSibNIGNI Publ., 1985. pp. 54-64.

15. Neruchev S.G. Uran $i$ zhizn $v$ istorii Zemli [Uranus and life in the history of the Earth]. Leningrad, Nedra Publ., 1982. 208 p.

16. Prinzio C.Y., Penaluna B., Grech M.G., Manzo L.M., Miserendino L.M., Casaux R. Impact of Chaitén Volcano ashfall on native and exotic fish recovery, recolonization, and abundance. Science of the Total Environment, 2021, vol. 752, article 141864

17. Afonin I.V., Tishin P.A., Hitarova A.V., Ernst R.E., Kudamanov A.V. Preliminary data on the connection of the CA 150 MA LIPs with the Bazhenov formatiom (Western Siberia). $7^{\text {th }}$ International Science Conference. Large Igneous Provinces through earth history: mantle plumes, supercontinents, climate change, metallogeny and oil-gas, planetary analogues. Tomsk, CSTI Publ. house, 2019. pp. 6-7.

18. Pierce J.D. U-Pb geochronology of the Late Cretaceous Eagle Ford Shale, Texas; defining chronostratigraphic boundaries and volcanic ash source. Thesis of Master of Science in Geological Sciences. Austin, 2014. 144 p.

19. Pierce J.D., Ruppel S.C., Rowe H., Stockli D. Zircon U-Pb Geochronology and Sources of Volcanic Ash Beds in the Upper Cretaceous Eagle Ford Shale, South Texas. GCAGS Journal, 2016, vol. 5, pp. 253-274

20. Kontorovich A.E., Yan P.A., Zamiraylova A.G., Kostyreva E.A., Eder V.G. Classification of rocks of the bazhenov formation. Geology and Geophysics, 2016, vol. 57 (11), pp. 2034-2043. In Rus.
21. Eder V.G., Zamiraylova A.G., Zanin Yu.N., Zhigulskiy I.A. Osobennosti litologicheskogo sostava osnovnykh tipov razrezov bazhenovskoy svity [Features of the lithological composition of the main types of sections of the Bazhenov formation]. Geologiya nefti i gaza, 2015, no. 6, pp. 96-106.

22. Predtechenskaya E.A., Zlobina O.N., Burleva O.V. Mineralogicheskie i geokhimicheskie anomalii kak indikatory flyuidodinamicheskikh protsessov $\mathrm{v}$ yurskikh neftegazonosnykh otlozheniyakh Zapadno-Sibirskoy plity [Mineralogical and geochemical anomalies as indicators of fluid-dynamic processes in the Jurassic oil and gas deposits of the West Siberian plate]. Geologiya, geofizika i razrabotka neftyanykh i gazovykh mestorozhdeniy, 2015, no. 1, pp. 11-24.

23. Zubkov M.Yu. Regional and local prediction of oil and gas occurrence for bazhenov and abalak formations in the Western Siberia. Mining statements, 2016, no. 3-4, pp. 46-68. In Rus.

24. Kotelnikov D.D., Konyukhov A.I. Glinistye mineraly osadochnykh porod [Clay minerals of sedimentary rocks]. Moscow, Nedra Publ., 1986. $247 \mathrm{p}$

25. Arbuzov S.I., Mezhibor A.M., Spears D.A., Ilenok S.S., Shaldybin M.V., Belaya E.V. Nature of Tonsteins in the Azeisk Deposit of the Irkutsk Coal Basin (Siberia, Russia). International Journal of Coal Geology, 2016, vol. 152, pp. 99-111.

26. Spears D.A. The origin of tonsteins, an overview, and links with seatearths, fireclays and fragmental clay rocks. International Journal of Coal Geology, 2012, vol. 94, pp. 22-31.

27. Lyons P.C., Spears D.A., Outerbridge W.F., Congdon R.D., Evans H.T. Euramerican tonsteins: overview, magmatic origin, and depositional-tectonic implications. Palaeogeography, Palaeoclimatology, Palaeoecology, 1994, vol. 106, pp. 113-134.

28. Dai S., Ward C.R., Graham I.T., French D., Hower J.C., Zhao L., Wang X. Altered volcanic ashes in coal and coal-bearing sequences: a review of their nature and significance. Earth-Science Reviews, 2017, vol. 175, pp. 44-74.

29. Bohor B.F., Triplehorn D.M. Tonsteins: altered volcanic ash layers in coalbearing sequences. Colorado, The Geological Society of America, 1993. $42 \mathrm{p}$

Received 24 December 2020.

Information about the authors

Elena S. Kondrashova, engineer National Research Tomsk Polytechnic University; engineer JSC «TomskNIPIneft». 